\title{
Occurrence of Aflatoxin B1 in Animal Feed Collected from the Northeastern Area of Morocco
} \author{
Houda Hafid ${ }^{1}$ and Oussama El Ouahabi ${ }^{1}$ \\ ${ }^{1}$ Laboratory of Analysis and Research-ONSSA, Avenue Ibn Toumert B.P. 3, Tangier, Morocco \\ ${ }^{2}$ Agronomic and Veterinary Institute HASSAN II, Madinat Al Irfane B.P. 6202, Rabat, Morocco \\ *Corresponding author’s Email: naoual.alahlah@yahoo.fr, (DORCiD: 0000-0003-3581-8294
}

Naoual Alahlah ${ }^{1,2 *}$, Mohammed El Maadoudi ${ }^{1}$, Nourredine Bouchriti ${ }^{2}$, Réda Triqui ${ }^{2}$, Meriem Stitou ${ }^{1}$, Nour

\begin{abstract}
The carry-over of contaminants from feed to animal products is an important issue in the animal production chain, therefore, the quality control of those animal products should include the control of the animal feed. The current study was carried out to assess the contamination levels of three types of animal feed (dairy animal feed, poultry feed, and fish feed) by Aflatoxin B1. A total of 68 animal feed samples were collected from the Northeastern Moroccan area (Tangier-Tétouan-AL Hoceima). The samples were extracted with a mixture of acetone/water. The sample extractions were filtered, diluted with phosphate-buffered saline, and applied to an immunoaffinity column. Aflatoxin B1 was eluted with methanol then analyzed by high-performance liquid chromatography with fluorescence detection, after post-column photochemical derivatization. The analytical results for the level of Aflatoxin B1 in the animal feed samples revealed an average presence of $44.12 \%$ for all analyzed samples. The concentrations were between 1.02 and $13.59 \mu \mathrm{g} / \mathrm{Kg}$, with a mean value of $4.08 \pm 3.11 \mu \mathrm{g} / \mathrm{Kg}$. The results indicated that there was a significant difference across the three types of animal feeds regarding the concentrations of Aflatoxin B1.
\end{abstract}

Keywords: Aflatoxin B1, Animal feed, HPLC, Morocco, Statistical data

\section{INTRODUCTION}

Aflatoxins are mycotoxins secreted by the species of Aspergillus, mainly Aspergillus species. Aflatoxin B1 (AFB1) is well known to be the most dangerous mycotoxin for humans. It is commonly found in a wide variety of food and feedstuffs (Oplatowska et al., 2016; Zinedine et al., 2016; Sasiprapa et al., 2018). This substance is classified in Group1 of carcinogenic agents for humans (IARC, 2002; Ostry et al., 2017).

The consequences of food and animal feed contamination by aflatoxin B1 have been widely investigated. With acute or chronic intoxication, teratogenic, mutagenic, carcinogenic, immunotoxic, or hepatotoxic effects of aflatoxins were well documented and discussed, especially for dairy cattle and poultry (Mckean et al., 2006; Klingelhofer et al., 2018; Sirma et al., 2018). Recently, toxic effects of aflatoxins on human astrocytes and human gastric smooth muscle cells were investigated (Omotayo et al., 2019; Park et al., 2019 a).

Aflatoxins in animal feed exert detrimental effects at three levels of animal health, human health through the consumption of contaminated products of animal origin, and subsequent economic losses due to the seizure and destruction of the incriminated lots. For different animal species, many studies have looked at aflatoxin's effects on animal health. General health problems, such as diarrhea, mastitis, and respiratory disorders were reported in herds (Quezada et al., 2000; Yiannikouris and Jouany, 2002; Rawal et al., 2010; Alam et al., 2020). Other effects have been listed, including attenuation of cell viability and induction of endoplasmic reticulum-mediated cell death in a bovine mammary epithelial cell line (Park et al., 2019b). Additional effects on embryonic development and attenuation of sperm viability in cattle (Komsky et al., 2018; Jiang et al., 2019), toxico-pathological effects in broiler chickens (Kashif et al., 2020) as well as disruption of the blood-brain barrier and affection of fish behavior (Ayyat et al., 2018; Baldissera et al., 2018) were also reported.

The above-mentioned effects have two consequences. First, contamination of animal products including milk, eggs, and meat, leads to adverse effects on human health (Costamagna et al., 2019; Adegbeye et al., 2020; Elzupir and Abdulkhair, 2020). Second, a reduction of reproductivity (poultry, aquaculture, and dairy production) leads to important economic losses (Ayyat et al., 2018; Alam et al., 2020; Yang et al., 2020). Aware of all these consequences, several studies have been carried out by many countries with the aim of determining the natural presence of aflatoxins in animal feed (Khayoon et al., 2010; Arroyo-Manzanares et al., 2015; Xiong et al., 2018). However, a large number of studies in different countries have focused mainly on the occurrence of AFB1 eliminated in the form of Aflatoxin M1 in dairy 
animal feed due to the importance of milk contamination in human health, especially children. The aim of those studies was to investigate the carryover rate of AFB1 from feed to milk and to determine contamination levels of this important animal product (Battacone et al., 2003; Xiong et al., 2013; Alahlah et al., 2020).

To manage the risk associated with animal feed contamination, analysis methods were developed and regulatory limits for feed were set. At the analytical level, from TLC to LC-MS/MS, the determination of aflatoxins in food and feed has undergone a marked evolution (Shephard, 2009). At the regulatory level, several health authorities have established limits for AFB1 in feedstuffs. In European Legislation 574/2011/EC (Official Journal of the European Union, 2011), the maximum level of AFB1 in complementary and complete feed is $0.01 \mathrm{mg} / \mathrm{kg}(10 \mu \mathrm{g} / \mathrm{kg})$, except for dairy and young animals for which maximum levels are $0.005 \mathrm{mg} / \mathrm{kg}(5 \mu \mathrm{g} / \mathrm{kg})$. For other livestock, these levels are capped at $0.02 \mathrm{mg} / \mathrm{kg}$ $(20 \mu \mathrm{g} / \mathrm{kg})$. Those values are relative to a feed with a moisture value of $12 \%$. The same maximum levels are established by Moroccan regulations (Bulletin Officiel N 6184, 2016).

In Morocco, the first report on the contamination of animal feed dealt with poultry feed with a total number of 315 samples (Kichou and Wasler, 1993). Another subsequent study by Zinedine et al. (2007), including poultry feed (21 samples) revealed an incidence of $66.6 \%$.

The present study aimed to investigate Aflatoxin B1 contamination levels, in three types of animal feed intended for dairy farms, poultry, and aquaculture fish.

\section{MATERIALS AND METHODS}

\section{Sampling}

A total of 68 samples of animal feed (44 dairy cattle feed, 12 poultry feed, and 12 fish feed) were collected in the northeastern area of Morocco, from October 2019 to July 2020. Samples, of $2 \mathrm{~kg}$ approximately each, were ground in a laboratory mill to ensure homogeneity and they were analyzed immediately.

\section{Reagents}

Liquid chromatography grade acetone, acetonitrile, and methanol, and phosphate buffered saline (PBS) were supplied by Sigma-Aldrich (Steinheim, Germany). The LC grade water was obtained by filtering deionized water with MilliQ system. Powders of Aflatoxin standards B1 were supplied by N'Tox (Novakits, France), and kept frozen at $-20^{\circ} \mathrm{C}$ in darkness. Working solutions of $100 \mathrm{ng} / \mathrm{mL}$ AFB1 were prepared from the stock solution containing $1 \mu \mathrm{g} / \mathrm{mL}$ into acetonitrile-water $(1 \mathrm{~V} / 9 \mathrm{~V})$ and were used to obtain a calibration curve ranging from 0.2 to $4 \mathrm{ng} / \mathrm{mL}$. The dilution was made with methanol up to $4 \mathrm{~mL}$ and further diluted with water up to $10 \mathrm{~mL}$ (AOAC, 2005)

\section{Apparatus}

The cleanup was achieved with an immuno-affinity column (Afla Clean select, LCTech GmbH, Germany) using a vacuum extraction manifold system. The chromatography was performed on a Perkin Elmer series 200 system coupled with the fluorescence detector Perkin Elmer Flexar (HTDS, France). A Sepax Bio-C18 reverse-phase column $(150 \times 4.6$ $\mathrm{mm}, 5 \mu \mathrm{m}, 300 \mathrm{~A})$ with guard column $\mathrm{C} 18(30 \times 4.6 \mathrm{~mm}, 5 \mu \mathrm{m})$ was used for the chromatographic separation. The postcolumn derivatization was realized with a Photochemical derivatization device- PHRED CE-12 with a knitted reactor coil KRC 20-25, provided by Aura Industries, USA (Joshua, 1993).

\section{Methods}

Extraction and immune-affinity clean-up were performed according to the AOAC Official Method 2003.02 (AOAC, 2005), and the manipulations were done in the dark.

\section{Extraction}

A test portion of $50 \mathrm{~g}( \pm 0.1 \mathrm{~g})$ was weighed into a $500 \mathrm{ml}$ flask, an extraction solvent (acetone/water, 85:15 v/v) was added. The mixture was shaken by hand for the first 15-30 s and then for 30 minutes with a flask shaker. The extract was filtered through a qualitative cellulose grade 4 Whatman paper filter and $5 \mathrm{ml}$ of the filtered sample were taken into a $100 \mathrm{ml}$ calibrated flask, diluted to volume with phosphate-buffered saline ( $\mathrm{pH} 7.4)$, and then filtrated through a glass microfiber GF /A filter to obtain a clear solution (AOAC, 2005).

\section{Immunoaffinity column clean up}

The manufacturer's instructions concerning column conditioning were followed. The columns were brought to room temperature, the liquid contained was evacuated and a small portion was maintained on the top of the column until the sample solution was applied. Then, $50 \mathrm{~mL}$ of the filtered sample extract was passed through the column by gravity at a flow rate of approximately $3 \mathrm{~mL} / \mathrm{min}$ (approximately 1-2 drops per second). The immunoaffinity column (IAC) was washed with $2 \times 10 \mathrm{~mL}$ of water at a flow rate of a maximum of $5 \mathrm{~mL} / \mathrm{min}$ and then allowed the column to run dry by 
applying a little vacuum (AOAC, 2005). The elution was carried out in 2 steps. Firstly, $0.5 \mathrm{~mL}$ of methanol was applied into IAC and collected by gravity in a calibrated $5 \mathrm{~mL}$ volumetric flask. After 1 min, the second volume of 1.25 $\mathrm{ml}$ methanol was applied and collected completely by pressing air through and diluted to volume with water. The elute was filtered through a filter unit 0.45 before High-performance liquid chromatography (HPLC) injection (AOAC, 2005)

\section{Derivatization}

The post-column photochemical derivatization was performed according to Joshua (1993). It is done automatically, using PHRED system placed between the LC column and the detector. AFB1 was transformed to their corresponding hemiacetals under UV light.

\section{High-performance liquid chromatography}

A volume of $100 \mu \mathrm{L}$ (in full loop injection mode) was injected; the flow rate was $1 \mathrm{~mL} / \mathrm{min}$ of the mobile phase containing water/acetonitrile/methanol solution $(70 / 18 / 12, \mathrm{v} / \mathrm{v} / \mathrm{v})$. Detection was made with a fluorescence detector, excitation and emission wavelengths were set at 365 and $435 \mathrm{~nm}$, respectively (AOAC, 2005). All samples were analyzed in duplicate.

\section{Statistical analysis}

Aflatoxin B1 concentrations $(\mu \mathrm{g} / \mathrm{kg})$ were calculated based on a calibration curve. ANOVA test was conducted and then the means of the three feeds were compared by Tukey test using SPSS Software (IBM SPSS Statistics V21 x86, USA). The level of significance was $\mathrm{p} \leq 0.05$. Results are presented as means \pm standard deviation.

\section{RESULTS AND DISCUSSION}

Results from AFB1 analytical determinations in the investigated feeds are summarized in Table 1. For the three animal feed types, the incidence of contamination was $44.12 \%$. Out of the 68 samples analyzed, 30 were found to be positive for AFB1. Concentration levels varied between $1.02 \mu \mathrm{g} / \mathrm{kg}$ (dairy animal feed) to $13.59 \mu \mathrm{g} / \mathrm{Kg}$ (Poultry feed), with a mean value of $4.08 \pm 3.11 \mu \mathrm{g} / \mathrm{Kg}$. Segregation of the results by the type of feed indicated an incidence of contamination of $40.91 \%$ in dairy animal feed (18 samples out of 44). The concentrations varied between 1.02 and $4.13 \mu \mathrm{g} / \mathrm{Kg}$, with a mean value of $2.66 \pm 0.9 \mu \mathrm{g} / \mathrm{Kg}$. All results were below $5 \mu \mathrm{g} / \mathrm{Kg}$.

In poultry feed, 7 samples were found to be contaminated (58.33\%). The concentrations varied between 1.11 and $13.59 \mu \mathrm{g} / \mathrm{Kg}$, with a mean value of $5.96 \pm 4.75 \mu \mathrm{g} / \mathrm{Kg}$. The Moroccan regulatory level is capped at $20 \mu \mathrm{g} / \mathrm{kg}$. A proportion of $41.67 \%$ of AFB1 levels in fish feed samples was above the limit of quantification. Concentration levels ranging between 2.08 and $9.47 \mu \mathrm{g} / \mathrm{Kg}$ were found, with a mean value of $6.58 \pm 3.08 \mu \mathrm{g} / \mathrm{Kg}$. None of the investigated samples exceeded the current regulatory maximum level of $10 \mu \mathrm{g} / \mathrm{kg}$.

Regardless of the number of samples, the analysis of the results showed that poultry feed is the most contaminated with the highest incidence, followed by fish feed and finally dairy animal feed. With respect to a level of significance $\mathrm{p} \leq$ 0.05 , the ANOVA and Tukey test made it possible to conclude that there was no difference between poultry and fish feed $(p>0.05)$ (while there was a significant difference between the concentrations of AFB1 in dairy animal feed as well as and in fish and poultry $(\mathrm{p} \leq 0.05)$ feed on the other hand (Table 2$)$.

Table 1. Occurrence of AFB1 in animal feed samples of the Northeastern area of Morocco

\begin{tabular}{|c|c|c|c|c|c|c|c|}
\hline Type of animal feed & \multicolumn{7}{|c|}{ Distribution of samples by AFB1 $(\mu \mathrm{g} / \mathrm{kg})$ concentration intervals } \\
\hline \multirow{7}{*}{$\begin{array}{l}\text { Dairy animal Feed }(n= \\
44)\end{array}$} & \multicolumn{3}{|c|}{$\geq 1-<5$} & \multicolumn{2}{|c|}{$\geq 5-<10$} & \multicolumn{2}{|c|}{$\geq 10-<20$} \\
\hline & $2.13 \pm 0.90$ & $2.1 \pm 0.90$ & $2.22 \pm 0.90$ & \multirow{6}{*}{\multicolumn{2}{|c|}{--}} & \multirow{6}{*}{\multicolumn{2}{|c|}{--}} \\
\hline & $2.51 \pm 0.90$ & $3.34 \pm 0.9$ & $2.01 \pm 0.90$ & & & & \\
\hline & $3.35 \pm 0.90$ & $2.14 \pm 0.9$ & $2.55 \pm 0.90$ & & & & \\
\hline & $4.13 \pm 0.90$ & $3.46 \pm 0.9$ & $1.33 \pm 0.90$ & & & & \\
\hline & $4.09 \pm 0.90$ & $2.80 \pm 0.90$ & $1.02 \pm 0.90$ & & & & \\
\hline & $3.56 \pm 0.90$ & $1.75 \pm 0.90$ & $3.35 \pm 0.90$ & & & & \\
\hline Poultry feed $(n=12)$ & $1.11 \pm 4.75$ & $1.23 \pm 4.75$ & $2.86 \pm 4.75$ & $5.33 \pm 4.75$ & $7.12 \pm 4.75$ & $10.45 \pm 4.75$ & $13.59 \pm 4.75$ \\
\hline \multirow{2}{*}{ Fish feed $(n=12)$} & \multirow{2}{*}{\multicolumn{3}{|c|}{$2.08 \pm 3.08$}} & $9.47 \pm 3.08$ & $6.94 \pm 3.08$ & \multirow{2}{*}{\multicolumn{2}{|c|}{-- }} \\
\hline & & & & $5.14 \pm 3.08$ & $9.25 \pm 3.08$ & & \\
\hline
\end{tabular}


Table 2. Differences between the tree studied animal feed

\begin{tabular}{|c|c|c|c|c|c|c|c|}
\hline \multirow{2}{*}{ (I) Feed } & \multirow{2}{*}{\multicolumn{2}{|c|}{ (J) Feed }} & \multirow{2}{*}{$\begin{array}{c}\text { Mean } \\
\text { Difference (I-J) }\end{array}$} & \multirow{2}{*}{$\begin{array}{c}\text { Standard } \\
\text { Error }\end{array}$} & \multirow{2}{*}{ Significance } & \multicolumn{2}{|c|}{$\mathbf{9 5 \%}$ Confidence interval } \\
\hline & & & & & & Lower Bound & Upper Bound \\
\hline \multirow{6}{*}{ Tukey Test } & \multirow{2}{*}{$\begin{array}{l}\text { Dairy } \\
\text { Animal }\end{array}$} & Poultry & $-3.38794 *$ & 1.17 & 0.020 & -6.2945 & -0.4814 \\
\hline & & Fish & $-3.91822 *$ & 1.33 & 0.017 & -7.2169 & -0.6196 \\
\hline & \multirow{2}{*}{ Poultry } & Dairy Animal & $3.38794 *$ & 1.17 & 0.020 & 0.4814 & 6.2945 \\
\hline & & Fish & 0.53029 & 1.54 & 0.937 & -4.3510 & 3.2905 \\
\hline & \multirow{2}{*}{ Fish } & Dairy Animal & $3.91822 *$ & 1.33 & 0.017 & 0.6196 & 7.2169 \\
\hline & & Poultry & 0.53029 & 1.54 & 0.937 & -3.2905 & 4.3510 \\
\hline
\end{tabular}

*The mean difference is significant at the level of 0.05 in a row.

In 2018, the production of poultry meat in Morocco reached 670000 metric tons and that of eggs was more than 5.8 billion units as reported by Fisa Maroc (2020). These values have been the highest since 2008. To reach these levels, feed production has also much evolved. In 2018, the production of poultry feed was 3.4 million metric tons. While the dairy feed is based on fodder production and agro-industry by-products, poultry feed is based only on industrialized feed ( $90 \%$ of the feed industry is focused on poultry feed). This may allow us to conclude that such a feed is the most likely to be contaminated by aflatoxins during production, transport, and/or storage and thus to have a tentative explanation for the high incidence found on a small number of samples.

For dairy animal feed, the obtained result of the current study indicated that the incidence was similar to that reported in other countries. Incidences of $42 \%(n=200), 35.1 \%(n=174)$, and $41.96 \%(n=210)$ were reported from China during two studies (Han et al., 2013; Xiong et al., 2018) and Iran (Ehsani et al., 2016) respectively. When comparing the results of the present study with those from some African countries, the incidence of AFB1 in the present study is lower than incidences reported in Nigeria (86.8\%) by Omeiza et al. (2018), and Kenya (86\%) by Kang'ethe and Lang'a (2009). In some countries of southern Europe, with a Mediterranean climate, the presence of aflatoxin B1 in dairy animal feed with low incidences has been reported as14.9\% in Portugal (Martins et al., 2007) and 8.1\% in Italy (Decastelli et al., 2007). Differences in incidence between countries can be explained by the colder climatic conditions and by the reinforced feed control system in these countries.

The transfer of Aflatoxin B1 from feed to milk has been investigated by several authors (Battacone et al., 2003; Xiong et al., 2013; Costamagna et al., 2019). The carryover rate varied among the different studies. In dairy cattle, an average AFB1 carryover rate estimated at 0.84\% was reported from Argentina (Costamagna et al., 2019) while a carryover estimated at $0.56 \%$ was reported from China (Xiong et al., 2013). In dairy ewes, a lower carryover rate of $0.112 \%$ was reported from Italy (Battacone et al., 2003). The current results may explain the occurrence of aflatoxin M1 in Ultra Hight Temperature (UHT) milk (35\% incidence) and powdered milk (100\% incidence) as evidenced from a previous study involving samples collected in the northern area of Morocco (Alahlah et al., 2020). Concentrations up to $44 \mathrm{ng} / \mathrm{Kg}$ were found in UHT milk, with an average concentration of $14.76 \pm 10.21 \mathrm{ng} / \mathrm{Kg}$. Nevertheless, actual confirmation awaits future analysis of a larger number of dairy animals' feed samples.

With respect to AFB1 determinations in poultry feed in Morocco, the current levels are much lower as compared to the results of Kichou and Wasler (1993) with concentrations ranging from 20 to $5625 \mu \mathrm{g} / \mathrm{kg}$. However, the current incidence is close to that reported by Zinedine et al. (2007) with a value of $66.6 \%$ based on 21 analyzed samples. The carryover rate of aflatoxin B1 from feed to eggs and laying hens (meat, liver, kidneys, and gizzards) has not been investigated as for milk, but AFB1 has been detected in such animal products (Quezada et al., 2000; Hussain et al., 2010; Alam et al., 2020).

Regarding the presence of AFB1 in fish feed, and to our knowledge, this is the first report of aflatoxin B1 in this type of feed in Morocco. The development of the aquaculture sector in Morocco has led the National competent authority of food safety (ONSSA) to set up a residue monitoring program for this type of feed. Although studies on the contamination of fish flesh with AFB1 are scarce, some have still looked at the effect of AFB1 on fish behavior and growth performances (Ayyat et al., 2018; Baldissera et al., 2018).

Whether for poultry feed or fish feed, the limited number of investigated samples may not allow a true risk assessment. However, the results of the present study should drive an alert on underlying risks in animal feed safety with the necessary strengthening of official control over the entire production chain along with the implementation of good hygienic and manufacturing practices and quality assurance programs. 


\section{CONCLUSION}

Findings of the current study revealed that no sample exceeded the limit of contamination set by the national authority and EU, however, a study on a large number of samples should be carried out to confirm these results, in particular for poultry feed. The incidence of $40.91 \%$ obtained for dairy animal feed should be taken into account. A study on aflatoxin M1 in raw milk becomes necessary to verify whether or not the level of contamination of cattle feed affects the quality of the milk. Poultry feed with an incidence of 58.33\% should raise awareness of the national authorities with respect to strengthening the already used monitoring programs. Considering the fish feed, national studies on the quality of the products must be carried out to better exploit the results currently found in the current study.

\section{DECLARATIONS}

\section{Authors' contributions}

Naoual Alahlah conceived of the presented idea. Naoual Alahlah, Mohammed El Maadoudi, Nourredine Bouchriti, and Reda Triqui developed the theory and performed the computations. Meriem Stitou, Nour Houda Hafid and Oussama El Ouahabi carried out the experiment in animal feed samples. Naoual Alahlah, Mohammed El Maadoudi, and Nourredine Bouchriti verified the analytical methods and supervised the findings of this work. Naoual Alahlah wrote the manuscript with support from Mohammed El Maadoudi, Nourredine Bouchriti and Reda Triqui.

All authors discussed the results and contributed to the final manuscript.

\section{Funding}

The current study was funded by the Laboratory of analysis and research Tangier-ONSSA. Office National de la sécurité Sanitaire des produits Alimentaire-Morocco

\section{Competing interests}

All authors declare no competing interests are to be reported.

\section{Acknowledgments}

The authors acknowledge the National office of Food Safety ONSSA-Morocco for the financial support. They are grateful to Mr. Michelangelo Pascale and Mrs. Eliene Alves for their precious contribution.

\section{Ethical considerations}

Ethical issues (including plagiarism, consent to publish, misconduct data and/or falsification, double publication and/or submission, and redundancy) have been checked before submission.

\section{REFERENCES}

Adegbeye MJ, Reddy PRK, Chilaka CA, Balogun OB, Elghandour MMYM, Rivas-Caceres RR, and Salem AZM (2020). Mycotoxin toxicity and residue in animal products: Prevalence, consumer exposure and reduction strategies - A review. Toxicon, 177: 96108. DOI: https://www.doi.org/10.1016/j.toxicon.2020.01.007

Alahlah N, EL Maadoudi M, Bouchriti N, Triqui R, and Bougtaib H (2020). Aflatoxin M1 in UHT and powder milk marketed in the northern area of Morocco. Food Control, 114: 107262. DOI: https://www.doi.org/10.1016/j.foodcont.2020.107262

Alam S, Khan NA, Muhammad A, Jan I, Hashmi MS, Khan A, and Khan MO (2020). Carryover of aflatoxin B1 from feed to broilers' tissues and its effect on chicken performance. Fresenius Environmental Bulletin, 29: 214-221. Available at: https://www.prtparlar.de/download_feb_2020/

Arroyo-Manzanares N, Hueras-Pérez JF, Garcia-Campana AM, and Gamiz-Gracia L (2015). Aflatoxins in animal feeds: A straightforward and cost-effective analytical method. Food Control, 54: 74-78. DOI: https://www.doi.org/10.1016/j.foodcont.2015.01.027

Association of Official Analytical Chemists (AOAC) (2005). Aflatoxin B1 in Cattle Feed. Immunoaffinity Column Liquid Chromatography Method. http://www.aoacofficialmethod.org/index.php?main_page=product_info\&cPath=1\&products_id=1950

Ayyat MS, Ayyat AMN, Al-Sagheer AA, and El-Hais AM (2018). Effect of some safe feed additives on growth performance, blood biochemistry and bioaccumulation of aflatoxin residues of Nile tilapia fed aflatoxin-B1 contaminated diet. Aquaculture, 495: $27-$ 34. DOI: https://www.doi.org/10.1016/j.aquaculture.2018.05.030

Baldissera MD, Souza CF, Zeppenfeld CC, Descovi SN, Moreira KLS, Da Rocha MIUM, Da Veiga ML, Da Silva AS, and Baldisserotto B (2018). Aflatoxin B1-contaminated diet disrupts the blood-brain barrier and affects fish behavior: Involvement of neurotransmitters in brain synaptosomes. Environmental Toxicology and Pharmacology, 60: 45-51. DOI: https://www.doi.org/10.1016/j.etap.2018.04.003 
Battacone G, Nudda A, Cannas A, Cappio Borlino A, Bomboi G, and Pulina G (2003). Excretion of aflatoxin M1 in milk of dairy ewes treated with different doses of aflatoxin B1. Journal of Dairy Science, 86: 2667-2675.

DOI: https://www.doi.org/10.3168/jds.s0022-0302(03)73862-4

Bulletin Officiel No 6518-2016 Arrêté conjoint du ministre de l'agriculture et de la pêche maritime et du ministre de la santé ${ }^{\circ} 1643$ 16 du 23 chaâbane 1437 (30 mai 2016) fixant les limites maximales autorisées des contaminants dans les produits primaires et les

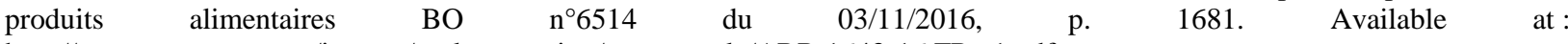
http://www.onssa.gov.ma/images/reglementation/transversale/ARR.1643-16.FR.c1.pdf

Costamagna D, Gaggiotti M, Chiericatti CA, Costabel L, Audero GML, Taverna M, and Signorini ML (2019). Quantification of aflatoxin M1 carry-over rate from feed to soft cheese. Toxicology Reports, 6: 782-787. DOI: https://www.doi.org/10.1016/j.toxrep.2019.07.004

Decastelli L, Lai J, Gramaglia M, Monaco A, Nachtmann C, Oldano F, Ruffier M, Sezian A, and Bandirola C (2007). Aflatoxins occurrence in milk and feed in Northern Italy during 2004-2005. Food Control, 18: 1263-1266. DOI: https://www.doi.org/10.1016/j.foodcont.2006.08.006

Ehsani A, Barani A, and Nasiri Z (2016). Occurrence of aflatoxin B1 contamination in dairy cows feed in Iran. Toxin Reviews, 35: 12. DOI: https://www.doi.org/10.3109/15569543.2016.1155622

Elzupir AO, and Abdulkhair BY (2020). Health risk from aflatoxins in processed meat products in Riyadh, KSA. Toxicon, 181: 1-5. DOI: https://www.doi.org/10.1016/j.toxicon.2020.04.092

Fisa Maroc (2020). Inter-professional Federation of the poultry Sector in Morocco. Présentation du secteur avicole, Available at : https://www.fisamaroc.org.ma/index.php?option=com_content\&view=article\&id=65\&Itemid=49

Han RW, Zheng N, Wang JQ, and Zhen YP (2013). Survey of Aflatoxin in dairy cow feed and raw in China. Food Control, 34 : 35-39. DOI: https://www.doi.org/10.1016/j.toxicon.2020.04.092

Hussain Z, Zargham KM, Khan A, Javed I, Kashif Saleemi M, Mahmood S, and Asi MR (2010). Residues of aflatoxin B1 in broiler meat: Effect of age and dietary aflatoxin B1 levels. Food and Chemical Toxicology, 48: 3304-3307. DOI: https://www.doi.org/10.1016/j.fct.2010.08.016

International Agency for Research on Cancer (IARC) (2002). Monograph on the evaluation of carcinogenic risk to humans. World Health Organization, 82: 171-175. Available at: https://publications.iarc.fr/Book-And-Report-Series/Iarc-Monographs-On-TheIdentification-Of-Carcinogenic-Hazards-To-

Humans\#: :text=The\%20IARC\%20Monographs\%20on\%20the,the\%20weight\%20of\%20the\%20evidence

Jiang Y, Hansen PJ, Xiao Y, Amaral TF, Vyas D, and Adesogan AT (2019). Aflatoxin compromises development of the preimplantation bovine embryo through mechanisms independent of reactive oxygen production. Journal of Dairy Science, 102: 10506-10513. DOI: https://www.doi.org/10.3168/jds.2019-16839.

Joshua H (1993). Determination of aflatoxins by reversed-phase high performance liquid chromatography with post-column in-line photochemical derivatization and fluorescence detection. Journal of Chromatography A, 654: 247-254. DOI: https://www.doi.org/10.1016/0021-9673(93)83367-2

Kang'ethe EK, and Lang'a KA (2009). Aflatoxin B1 and M1 contamination of animal feeds and milk from urban centers in Kenya. African Health Sciences, 9(4): 218-226. Available at: https://pubmed.ncbi.nlm.nih.gov/21503172/

Kashif SM, Ashraf K, Tehseen GS, Noman NM, Sohail SM, Mohsin M, He C, Zubair M, and Khan A (2020). Toxicopathological effects of feeding aflatoxins B1 in broilers and its ameliosration with indigenous mycotoxin binder. Ecotoxicology and Environmental Safety, 187: 109712. DOI: https://www.doi.org/10.1016/j.ecoenv.2019.109712

Khayoon SW, Bahruddin S, Bee YC, Hasani HN, Salhin MAA, Idris SM, and Baharuddin S (2010). Determination of aflatoxins in animal feeds by HPLC with multifunctional cllumn clean up. Food Control, 118: 882-886. DOI: https://www.doi.org/10.1016/j.foodchem.2009.05.082

Kichou F, and Wasler MM (1993). The natural occurrence of aflatoxin B1 in Moroccan poultry feed. Veterinary and Human Toxicology, 35: 105-108. Available at: https://pubmed.ncbi.nlm.nih.gov/8470350/

Klingelhofer D, Zhu Y, Braun M, Bendels MHK, Bruggmann D, and Groneberg DA (2018). Aflatoxin-Publication analysis of a global health threat. Food Control, 89: 280-290. DOI: https://www.doi.org/10.1016/j.foodcont.2018.02.017

Komsky EA, Saktsier M, and Roth Z (2018). Aflatoxin B1 impairs sperm quality and fertilization competence. Toxicology, 393: 4250. DOI: https://www.doi.org/10.1016/j.tox.2017.11.007

Martins MH, Mendes GMM, and Bernardo FM (2007). Occurrence of aflatoxin B1 in dairy cow's feed over 10 years in Portugal (1995-2004). Revista Iberoamericana de Micología, 24: 69-71. Available at: https://citeseerx.ist.psu.edu/viewdoc/download?doi=10.1.1.597.61\&rep=rep1\&type=pdf

McKean C, Tang L, Tang M, Billam M, Wang Z, Theodorakis CW, Kendall RJ, and Wang JS (2006). Comparatice acute and combinative toxicity of Aflatoxin B1 and Fumonisin B1 in animals and human cells. Food and Chemical Toxicology, 44: 868876. DOI: https://www.doi.org/10.1016/j.fct.2005.11.011

Official Journal of the European Union (2011). Commission Regulation (EC) N.574/2011 of 16 June amending Annex I to Directive 2002/32/EC of the European Parliament and of the Council as regards maximum levels for nitrite, melamine, Ambrosia spp. and carry-over of certain coccidiostats and histomonostats and consolidating Annexes I and II thereto. Available at : https://eurlex.europa.eu/LexUriServ/LexUriServ.do?uri=OJ:L:2011:159:0007:0024:FR:PDF\#: :text=Il\%20convient\%20d\%C3\%A8s\%201o rs\%20de,en\%20graines\%20d'Ambrosia\%20spp.

Omeiza GK, Kabir J, Kwaga JKP, Kwanashie CN, Mwanza M, and Ngoma L (2018). A risk assessment study of the occurrence and distribution of aflatoxigenic Aspergillus flavus and aflatoxin B1 in dairy cattle feeds in a central northern state, Nigeria. Toxicology Reports, 5: 846-856. DOI: https://www.doi.org/10.1016/j.toxrep.2018.08.011

Omotayo OP, Omotayo AO, Babalola OO, and Mwanza M (2019). Dataset on the toxic effect of aflatoxin and ochratoxin a on the human gastric smooth muscle cells. Data in Brief, 25: 104089. DOI: https://www.doi.org/10.1016/j.dib.2019.104089 
Oplatowska SM, Sajic N, Xu Y, Haughey SA, Mooney M, Gong YY, Verheijen R, and Elliott CT (2016). Fast and sensitive aflatoxin B1 and total aflatoxins ELISAs for analysis of peanuts, maize and feed ingredients. Food Control, 63: 239-245. DOI: https://www.doi.org/10.1016/j.foodcont.2015.11.041

Ostry V, Malir F, Toman J, and Grosse Y (2017). Mycotoxins as human carcinogens - the IARC Monographs classification. Mycotoxin Research, 33(1): 65-73. DOI: https://www.doi.org/10.1007/s12550-016-0265-7

Park S, Lee JY, You S, Song G, and Lim W (2019a). Neurotoxic effects of aflatoxin B1 on human astrocytes in vitro and on glial cell development in Zebrafish in vivo. Journal of Hazardous Materials, 15: 386. DOI: https://www.doi.org/10.1016/j.jhazmat.2019.121639

Park W, Park MY, Song G, and Lim W (2019b). Exposure to aflatoxin B1 attenuates cell viability and induces endoplasmic reticulummediated cell death in a bovine mammary epithelial cell line (MAC-T). Toxicology in Vitro, 61: 104591. DOI: https://www.doi.org/10.1016/j.tiv.2019.104591

Quezada T, Cuellar H, Jaramillo-Jua'rez F, Valdivia AG, and Reyes JL (2000). Effects of aflatoxin B1 on the liver and kidney of broiler during development. Comparative Biochemistry and Physiology Part C, 125: 265-272. DOI: https://www.doi.org/10.1016/S0742-8413(99)00107-3

Rawal S, Kim JE, and Coulombe Jr R (2010). Aflatoxin B1 in poultry: Toxicology, metabolism and prevention. Reearch Veterinary Science, 89(201): 325-331. DOI: https://www.doi.org/10.1016/j.rvsc.2010.04.011

Sasiprapa C, Jutamas P, Prakorn J, and Thanapoom Natthasit T (2018). Determination of aflatoxin B 1 in feedstuffs without clean-up Step by high-performance liquid chromatography. International Journal of Analytical Chemistry, Article

ID

4650764.

DOI: https://www.doi.org/10.1155/2018/4650764

Shephard GS (2009). Aflatoxin analysis at the beginning of the twenty-first century. Analytical and Bioanalytical Chemistry, 395 : 1215-1224. DOI: https://www.doi.org/10.1007/s00216-009-2857-y

Sirma AJ, Lindahl JF, Makita K, Senerwa D, Mtimet N, Kang'ethe EK, and Grace D (2018). The impacts of aflatoxin standards on health and nutrition in sub-Saharan Africa: The case of Kenya. Global Food Security 18: 57-61. DOI : https://www.doi.org/10.1016/j.gfs.2018.08.001

Xiong J, Xiong L, Zhou H, Liu Y, and Wu L (2018). Occurrence of aflatoxin B1 in dairy cow feedstuff and aflatoxin M1 in UHT and pasteurized milk in central China. Food Control, 92: 386-390. DOI: https://www.doi.org/10.1016/j.foodcont.2018.05.022

Xiong JL, Wang YM, Nennich TD, Li Y, and Liu JX (2013). Transfer of dietary aflatoxin B1 to milk aflatoxin M1 and effect of inclusion of adsorbent in the diet of dairy cows. Journal of Dairy Science, 98: 2545-2554. DOI: http://www.dx.doi.org/10.3168/jds.2013-7842

Yang C, Song G, and Lim W (2020). Review- Effects of mycotoxin-contaminated feed on farm animals. Journal of Hazardous Materials, 389: 122087. DOI: https://www.doi.org/10.1016/j.jhazmat.2020.122087

Yiannikouris A, and Jouany JP (2002). Les mycotoxines dans les aliments des ruminants, leur devenir et leurs effets chez l'animal. INRAE Productions Animales, 15(1): 3-16. DOI: https://www.doi.org/10.20870/productions-animales.2002.15.1.3683

Zinedine A, Fernández-Franzón, M, Mañes J, and Manyes L (2016). Multi-mycotoxin contamination of couscous semolina commercialized in Morocco, Food Chemistry, 214: 440-446. DOI: http://www.dx.doi.org/10.1016/j.foodchem.2016.07.098

Zinedine A, Juan C, Soriano JM, Molto JC, Idrissi L, and Manes J (2007). Limited survey for the occurrence of aflatoxins in cereals and poultry feed from Rabat, Morocco. International Journal of Food Microbiology, 115: 124-127. DOI: http://www.dx.doi.org/10.1016/j.ijfoodmicro.2006.10.013 